\title{
STUDIES ON ACID ATTACK RESISTANCE OF LOW CALCIUM FLYASH AND SLAG BASED GEOPOLYMER CONCRETE
}

\author{
T Srinivas ${ }^{1}$, N V Ramana Rao ${ }^{2}$ \\ ${ }^{1}$ Research Scholar, Department of Civil Engineering, JNTUH, Hyderabad-500085 \\ ${ }^{2}$ Professor, Department of Civil Engineering, JNTUH, Hyderabad-500085
}

\begin{abstract}
It is required to bring down an effect of carbon dioxide, otherwise which leads to global warming as a result the researchers have started to search for sustainable building materials. Geopolymer concrete (GPC) is made using industrial waste like fly ash, silica fume (SF), rice husk ash (RHA) or GGBS. Alkali liquids (usually a soluble metal hydro-oxide and/or alkali silicate) can be used to react with silica (SiO2), alumina (Al2O3) and with fly ash to produce binders, such binders mixed with typical coarse and fine aggregates to form concrete, usually known as alkali activated concrete or geopolymer concrete. The main objective of this paper is to study the sustainable durability property like acid attack resistance on geopolymer concrete of M30 and M50 which are designated as G30 and G50 grades respectively. The alkaline solution used in this present study is combination of sodium silicate ( $\mathrm{Na2SiO3)}$ and sodium hydroxide ( $\mathrm{NaOH}$ ), the ratio of $\mathrm{Na} 2 \mathrm{SiO} 3$ to $\mathrm{NaOH}$ is 2.5 and $\mathrm{SiO} 2$ to $\mathrm{Na} 2 \mathrm{O}$ is 2, since the strength is maximum at these ratios. The test specimens were cast and after one day rest period, half of the test specimens were cured in an oven at $60^{\circ} \mathrm{C}$ for 24 hours and the remaining period cured in sun light until the testing is done and remaining half of the test specimens were ambient cured. After 28 days the specimens were immersed in acids such as HCL and H2SO4 for 15, 45, 75 and 105 days then tested on 15th, 45th, 75th and 105th day according to codal procedures and the results are compared with the controlled concrete. From the test results it is observed that the geopolymer concrete has high resistance to acids than controlled concrete.
\end{abstract}

Keywords: Fly Ash, Geopolymer Concrete, GGBS, Oven curing, Alkaline solution and Acids ****

\section{INTRODUCTION}

Even though the problem of hydrochloric and sulphuric acid corrosion in concrete sewer pipes is recognised, this problem has not been satisfactorily solved. A research looked at different ways of enhancing the acid resistance of ordinary Portland cement (OPC) based concretes, using the partial replacement of ordinary Portland cement by supplementary materials. The acid attack in terms of mass loss was reduced; Hydrochloric and sulphuric acid resistant binders are still required to improve the long-term performance of controlled concrete in acid corrosion environments. Geopolymer binders might be a promising alternative in the development of acid resistant concrete. Since Geopolymers are a novel binder that relies on alumina-silicate rather than calcium silicate hydrate bonds for structural integrity, they have been reported as being acid resistant. Many countries are promoting the use of fly ash and GGBS as building material by granting carbon credit, which will not only reduces the production of cement and emission of carbon dioxide but also promotes the consumption of the waste material fly ash which poses a major problem for disposal world over. In India there is abundant availability of fly ash because there are many thermal plants all over the country. The ingredients of the alkaline solution viz. sodium hydroxide and sodium silicates are cheap and locally available. Studies on the fly ash based geopolymer concrete dates back to three decades only. Most of the studies are done under heat cured regime since the polymerization process is fast at $60^{\circ} \mathrm{C}$ to $90^{\circ} \mathrm{C}$. Most parts of
India come under tropical region where the normal temperature during summer is above $30^{\circ} \mathrm{C}$. Geopolymer which is naturally cured at ambient outdoor temperature can be considered as a curing free concrete. The objective of the present investigation is to study acid attack resistance in terms of loss of compressive strengths and loss of weights of various grades of controlled and geopolymer concrete exposed to $5 \%$ concentrations of $\mathrm{HCL}$ and $\mathrm{H}_{2} \mathrm{SO}_{4}$.

\section{MATERIALS}

\subsection{Ordinary Portland Cement}

In the experimental investigations, 53-grade of ordinary Portland cement of Ultra-tech Brand is used. The cement thus procured was tested for physical properties in accordance with the IS: 4031-1968 and conformed various specifications of IS 12629-1987.

Table-1: Chemical Composition of Cement (Source: www.cement.org)

\begin{tabular}{|c|l|l|}
\hline S.NO. & Constituent & Percentage \\
\hline 1 & $\mathrm{CaO}$ & 63.70 \\
\hline 2 & $\mathrm{SiO}_{2}$ & 22.00 \\
\hline 3 & $\mathrm{Al}_{2} \mathrm{O}_{3}$ & 4.25 \\
\hline 4 & $\mathrm{Fe}_{2} \mathrm{O}_{3}$ & 3.40 \\
\hline 5 & $\mathrm{MgO}$ & 1.50 \\
\hline 6 & $\mathrm{SO}_{3}$ & 1.95 \\
\hline
\end{tabular}


Table 2: Physical Properties of Ordinary Portland Cement of 53 Grade

\begin{tabular}{|l|l|l|l|}
\hline S.No & $\begin{array}{l}\text { Characteristics } \\
\text { Properties }\end{array}$ & $\begin{array}{l}\text { Test } \\
\text { Results }\end{array}$ & $\begin{array}{l}\text { Requirements as per } \\
\text { IS 12269-1987 }\end{array}$ \\
\hline 1 & Normal consistency & $33 \%$ & ---- \\
\hline 2 & Specific gravity & 3.01 & 3.0 to 3.2 \\
\hline 3 & $\begin{array}{l}\text { Setting time of } \\
\text { cement } \\
\text { IST } \\
\text { FST }\end{array}$ & $\begin{array}{l}\text { Not less than 30 } \\
\text { minutes } \\
\text { Not more than 600 } \\
\text { minutes. }\end{array}$ \\
\hline 4 & $\begin{array}{l}\text { Soundness-Lechatlier } \\
\text { method }\end{array}$ & $\begin{array}{l}\text { Not more than 10 } \\
\text { mm }\end{array}$ \\
\hline 5 & $\begin{array}{l}\text { Fineness of cement } \\
\text { by sieving through } \\
\text { sieve } \\
\text { microns for a period } \\
\text { of 15 minutes }\end{array}$ & $\begin{array}{l}\text { 15\% } \\
\text { Compressive strength } \\
\text { at 28 days }\end{array}$ & 55 \\
\hline 6 & & \\
\hline
\end{tabular}

\subsection{Fine Aggregate}

In the present investigation, fine aggregate used is obtained from local sources. The sand is made free from clay matter, silt, and organic impurities and sieved on $4.75 \mathrm{~mm}$ IS sieve. The physical properties of fine aggregate are tested in accordance with IS: 2386 and the used sand is confirmed as Zone II of IS 383-1970.

\subsection{Coarse Aggregate}

The crushed angular aggregate of $20 \mathrm{~mm}$ maximum size from the local crushing plants is used as coarse aggregate in the present study. The physical properties of coarse aggregate such as specific gravity, bulk density, flakiness and elongation index are tested with IS: 2386-1963.

\subsection{Fly Ash}

Class F-fly ash is used, which is available from Vijayawada thermal power station in Andhra Pradesh. The typical composition of fly ash and chemical requirements are shown in table 3 and 4 respectively.

Table 3: Typical Oxide Composition of Fly Ash

\begin{tabular}{|l|l|l|}
\hline S.NO. & Constituent & Percentage \\
\hline 1 & $\mathrm{CaO}$ (Lime) & $0.7-3.6$ \\
\hline 2 & $\mathrm{SiO}_{2}$ (Silica) & $49-67$ \\
\hline 3 & $\mathrm{Al}_{2} \mathrm{O}_{3}$ (Alumina) & $16-28$ \\
\hline 4 & $\mathrm{Fe}_{2} \mathrm{O}_{3}$ (iron oxide) & $4-10$ \\
\hline 5 & $\mathrm{MgO}$ & $0.3-2.6$ \\
\hline 6 & $\mathrm{SO}_{3}$ & $0.1-1.9$ \\
\hline 7 & $\mathrm{Surface}$ area $\mathrm{m}^{2} / \mathrm{kg}$ & $230-600$ \\
\hline
\end{tabular}

Table 4: Chemical Requirement of Fly Ash (IS: 3812-part 1 2003)

\begin{tabular}{|l|l|l|l|}
\hline S.NO. & $\begin{array}{l}\text { Characteristics } \\
\text { (Percent by } \\
\text { mass) }\end{array}$ & $\begin{array}{l}\text { Minimum } \\
\text { Requirement } \\
\text { in \% }\end{array}$ & $\begin{array}{l}\text { Composition } \\
\text { of VTPS fly } \\
\text { ash in \% }\end{array}$ \\
\hline 1 & $\begin{array}{l}\mathrm{SiO}_{2}+\mathrm{Al}_{2} \mathrm{O}_{3} \\
+\mathrm{Fe}_{2} \mathrm{O}_{3}\end{array}$ & 70 & 86.75 \\
\hline 2 & $\mathrm{SiO}_{2}$ & 35 & 54 \\
\hline 3 & Reactive Silica & 20 & 25 \\
\hline 4 & $\begin{array}{l}\mathrm{MgO} \\
\mathrm{SO}_{3}(\text { Sulphur } \\
\text { trioxide) }\end{array}$ & 5 & 7 \\
\hline 5 & $\begin{array}{l}\text { Available alkali } \\
\text { as sodium oxide } \\
\left(\mathrm{Na}_{2} \mathrm{O}\right)\end{array}$ & 1.5 & 6 \\
\hline 6 & Loss of ignition & 5 & 2.16 \\
\hline 7 & \multicolumn{2}{|l}{} \\
\hline
\end{tabular}

\subsection{Ground Granulated Blast Furnace Slag}

GGBS shown in fig 2 is a by product of the steel industry. GGBS is defined as "the non-metallic product consisting essentially of calcium silicates and other bases that is developed in a molten condition simultaneously with iron in a blast furnace". About $15 \%$ by mass of binders was replaced with GGBS.

Table: 5 Chemical Compositions of GGBS

\begin{tabular}{|l|l|l|}
\hline S.No & Constituent & Percentage \\
\hline 1 & Silicon dioxide $\left(\mathrm{SiO}_{2}\right)$ & 33.2 \\
\hline 2 & Alumina tri-oxide $\left(\mathrm{Al}_{2} \mathrm{O}_{3}\right)$ & 18.3 \\
\hline 3 & $\left(\mathrm{Fe}_{2} \mathrm{O}_{3}\right)$ & 0.6 \\
\hline 4 & $(\mathrm{CaO})$ & 32.9 \\
\hline 5 & $(\mathrm{MgO})$ & 11.6 \\
\hline 6 & Sulphur tri-oxide $\left(\mathrm{SO}_{3}\right)$ & 1.0 \\
\hline 7 & Potassium oxide $\left(\mathrm{K}_{2} \mathrm{O}\right)$ & 0.91 \\
\hline 8 & Sodium oxide $\left(\mathrm{Na}_{2} \mathrm{O}\right)$ & 0.21 \\
\hline 9 & Chlorides $(\mathrm{Cl})$ & 0.006 \\
\hline
\end{tabular}

Table: 6 Physical Properties of GGBS

\begin{tabular}{|l|l|l|}
\hline $\begin{array}{l}\text { S } \\
\text { No }\end{array}$ & Characteristics & Result \\
\hline 1. & Colour & Dull white \\
\hline 2. & Fineness(Blaine's) $\mathrm{m}^{2} / \mathrm{kg}$ & 450 \\
\hline 3. & Specific Gravity & 2.91 \\
\hline 4. & Glass content percent & 93 \\
\hline 5. & Bulk Density $\mathrm{kg} / \mathrm{m}^{3}$ & 1100 \\
\hline
\end{tabular}

\subsection{Water}

Water free from chemicals, oils and other forms of impurities is to be used for mixing of concrete as per IS: 456:2000.

\subsection{Geopolymers}

Geopolymers are member of the family of inorganic polymers and are a chain structures formed on a backbone of $\mathrm{Al}$ and $\mathrm{Si}$ ions.

\subsubsection{Constituents of Geopolymer} 2.7.1.1 Source Materials 
Any material that contains mostly Silicon (Si) and Aluminium ( $\mathrm{Al}$ ) in amorphous form is a possible source material for the manufacture of geopolymer. Low calcium fly ash (ASTM Class F) is preferred as a source material than high calcium (ASTM Class C) fly ash. Among the byproduct materials only fly ash and slag have been proved to be the potential source materials for making geopolymers.

\subsubsection{Alkaline Activators}

The most common alkaline activator used in geopolymerisation is a combination of sodium hydroxide $(\mathrm{NaOH})$ or potassium hydroxide $(\mathrm{KOH})$ and sodium silicate $\left(\mathrm{Na}_{2} \mathrm{SiO}_{3}\right)$ or potassium silicate (Davidovits 1999; Palomo, Grutzeck et al. 1999; Barbosa, MacKenzie et al. 2000; Xu and van Deventer 2000; Swanepoel and Strydom 2002; Xu and van Deventer 2002).

\subsubsection{Superplasticiser}

High range water reducing (Master Glenium B233) super plasticizer was used in the mixtures at the rate of $1.5 \%$ of fly ash to increase the workability of the fresh geopolymer concrete.

\section{EXPERIMENTAL INVESTIGATION}

\subsection{General}

The aim of this paper is to present an experimental investigation on the behavior of fly ash and slag based geopolymer concrete exposed to 5\% acid solutions for up to 3.5 months of G30 and G50 which are equivalent to M30 and M50 grades respectively. In the present study an alkaline solution is used as combination of sodium silicate $\left(\mathrm{Na}_{2} \mathrm{SiO}_{3}\right)$ and sodium hydroxide. The ratio of $\mathrm{Na}_{2} \mathrm{SiO}_{3}$ to $\mathrm{NaOH}$ is 2.5 and $\mathrm{SiO}_{2}$ to $\mathrm{Na}_{2} \mathrm{O}$ is 2.09 has been used since the compressive strength is maximum at these ratios. The cubes of size $100 \mathrm{~mm} \times 100 \mathrm{~mm} \times 100 \mathrm{~mm}$ were cast and after one day rest period, half of the specimens were cured in an oven at $60^{\circ} \mathrm{C}$ for 24 hours and the remaining period cured in sun light until the specimens immersed in acids and remaining half of the specimens were ambient cured. After 28 days the specimens were immersed in acids such as HCL and $\mathrm{H}_{2} \mathrm{SO}_{4}$ for $15,45,75$ and 105 days then the acid attack resistance in terms of loss of compressive strengths and loss of weights of both grades of controlled and geopolymer concrete exposed to $5 \%$ concentrations of $\mathrm{HCL}$ and $\mathrm{H}_{2} \mathrm{SO}_{4}$. Acid Durability Factors (ADFs) and Acid Attack Factors (AAFs) of controlled and geopolymer concrete exposed to $5 \%$ concentrations of both acids are also evaluated to determine their resistance to acid attack and the obtained results have been studied and compared.

Table 7: Properties of $\mathrm{Na}_{2} \mathrm{SiO}_{3}$ Solution

\begin{tabular}{|l|l|}
\hline Specific gravity & 1.57 \\
\hline Molar mass & $122.06 \mathrm{gm} / \mathrm{mol}$ \\
\hline $\mathrm{Na}_{2} \mathrm{O}$ (by mass) & $14.35 \%$ \\
\hline $\mathrm{SiO} 2$ (by mass) & $30.00 \%$ \\
\hline Water (by mass) & $55.00 \%$ \\
\hline Weight ratio $\left(\mathrm{SiO}_{2}\right.$ to $\left.\mathrm{Na}_{2} \mathrm{O}\right)$ & 2.09 \\
\hline Molarity ratio & 0.97 \\
\hline
\end{tabular}

Table 8: Properties of $\mathrm{NaOH}$

\begin{tabular}{|l|l|}
\hline Molar mass & $40 \mathrm{gm} / \mathrm{mol}$ \\
\hline Appearance & White solid \\
\hline Density & $2.1 \mathrm{gr} / \mathrm{cc}$ \\
\hline Melting point & $318^{\circ} \mathrm{C}$ \\
\hline Boiling point & $1390^{\circ} \mathrm{C}$ \\
\hline $\begin{array}{l}\text { Amount of heat liberated } \\
\text { when dissolved in water }\end{array}$ & $266 \mathrm{cal} / \mathrm{gr}$ \\
\hline
\end{tabular}

Table 9: Mix proportions for G30 grade of Geopolymer concrete

\begin{tabular}{|c|c|c|}
\hline \multicolumn{2}{|l|}{ Grade of GPC } & G30 \\
\hline Fly ash $\left(\mathrm{Kg} / \mathrm{m}^{3}\right)$ & 307.7 & \multirow[t]{2}{*}{362} \\
\hline $\operatorname{GGBS}\left(\mathrm{Kg} / \mathrm{m}^{3}\right)$ & 54.3 & \\
\hline \multicolumn{2}{|c|}{ Fine Aggregate $\left(\mathrm{Kg} / \mathrm{m}^{3}\right)$} & 682.6 \\
\hline \multicolumn{2}{|c|}{ Coarse Aggregate $\left(\mathrm{Kg} / \mathrm{m}^{3}\right)$} & 1184.4 \\
\hline \multicolumn{2}{|c|}{$\begin{array}{l}\mathrm{NaOH} \text { solids out of } 46.54 \mathrm{Kg} / \mathrm{m}^{3} \\
\text { for } 12 \text { Molarity concentration in } \mathrm{Kg} / \mathrm{m}^{3}\end{array}$} & 16.80 \\
\hline \multicolumn{2}{|l|}{$\mathrm{Na}_{2} \mathrm{SiO}_{3}\left(\mathrm{Kg} / \mathrm{m}^{3}\right)$} & 116.36 \\
\hline \multicolumn{2}{|c|}{ Extra water $\left(\mathrm{Kg} / \mathrm{m}^{3}\right)$} & 20 \\
\hline \multicolumn{2}{|c|}{ SP(GLENIUM B233)@ 1\% $\left(\mathrm{Kg} / \mathrm{m}^{3}\right)$} & 3.62 \\
\hline \multicolumn{2}{|l|}{ Mix proportions } & $1: 1.89: 3.27$ \\
\hline \multicolumn{2}{|l|}{ Liquid/binder ratio } & 0.45 \\
\hline \multicolumn{2}{|l|}{ Workability (mm) } & 50 \\
\hline
\end{tabular}

Table 10: Mix Proportions of Controlled Concrete Expressed as Equivalent Proportions of GPC

\begin{tabular}{|l|l|}
\hline Concrete Grade & M30 \\
\hline Cement $\left(\mathrm{Kg} / \mathrm{m}^{3}\right)$ & 362 \\
\hline $\mathrm{FA}\left(\mathrm{Kg} / \mathrm{m}^{3}\right)$ & 682.6 \\
\hline $\mathrm{CA}\left(\mathrm{Kg} / \mathrm{m}^{3}\right)$ & 1184.4 \\
\hline $\mathrm{SP}(\mathrm{GLENIUM}) @ 1 \%\left(\mathrm{Kg} / \mathrm{m}^{3}\right)$ & 3.62 \\
\hline Mix proportions & $1: 1.89: 3.27$ \\
\hline W/C ratio & 0.45 \\
\hline Workability $(\mathrm{mm})$ & 50 \\
\hline
\end{tabular}

Table 11: Mix Proportions for G50 grade of Geopolymer Concrete

\begin{tabular}{|c|c|c|}
\hline \multicolumn{2}{|l|}{ Grade of GPC } & G50 \\
\hline Fly ash $\left(\mathrm{Kg} / \mathrm{m}^{3}\right)$ & 348.5 & \multirow{2}{*}{410} \\
\hline $\operatorname{GGBS}\left(\mathrm{Kg} / \mathrm{m}^{3}\right)$ & 61.5 & \\
\hline \multicolumn{2}{|l|}{$\mathrm{FA}\left(\mathrm{Kg} / \mathrm{m}^{3}\right)$} & 554.4 \\
\hline \multicolumn{2}{|l|}{$\mathrm{CA}\left(\mathrm{Kg} / \mathrm{m}^{3}\right)$} & 1293.6 \\
\hline \multicolumn{2}{|c|}{$\begin{array}{l}\mathrm{NaOH} \text { solids out of } 46.86 \mathrm{Kg} / \mathrm{m}^{3} \\
\text { For } 16 \text { Molarity concentration in } \mathrm{Kg} / \mathrm{m}^{3}\end{array}$} & 20.81 \\
\hline \multicolumn{2}{|l|}{$\mathrm{Na}_{2} \mathrm{SiO}_{3}\left(\mathrm{Kg} / \mathrm{m}^{3}\right)$} & 117.14 \\
\hline \multicolumn{2}{|c|}{ Extra water $\left(\mathrm{Kg} / \mathrm{m}^{3}\right)$} & 45 \\
\hline \multicolumn{2}{|c|}{ SP (GLENIUM)@ 1.5\% (Kg/m³) } & 6.15 \\
\hline
\end{tabular}




\begin{tabular}{|l|l|}
\hline Mix proportions & $1: 1.35: 3.16$ \\
\hline Liquid/binder ratio & 0.40 \\
\hline Workability (mm) & 50 \\
\hline
\end{tabular}

Table 12: Mix Proportions of OPC Controlled Concrete Expressed as Equivalent Proportions of GPC

\begin{tabular}{|l|l|}
\hline Grade of Concrete & M50 \\
\hline Cement $\left(\mathrm{Kg} / \mathrm{m}^{3}\right)$ & 410 \\
\hline FA $\left(\mathrm{Kg} / \mathrm{m}^{3}\right)$ & 554.4 \\
\hline CA $\left(\mathrm{Kg} / \mathrm{m}^{3}\right)$ & 1293.6 \\
\hline SP $\left.(\mathrm{GLENIUM}) @ 1.5 \% \mathrm{Kg} / \mathrm{m}^{3}\right)$ & 6.15 \\
\hline Mix proportions & $1: 1.35: 3.16$ \\
\hline W/C ratio & 0.40 \\
\hline Workability $(\mathrm{mm})$ & 50 \\
\hline
\end{tabular}

\subsection{Mixing and Casting of Geopolymer Concrete}

Geopolymer concrete is prepared by using the same procedure whatever is used in the conventional concrete. In the laboratory, the fly ash and the aggregates were mixed together in dry by using a pan mixer for about three minutes, then the alkaline liquid was mixed with the super plasticizer and extra water if any. The liquid component of the mixture was then added to the dry material and the mixing continued usually for another four minutes. The fresh concrete was cast and compacted by the usual methods used in the case of conventional concrete. The workability of the fresh concrete was measured by means of the conventional slump test.
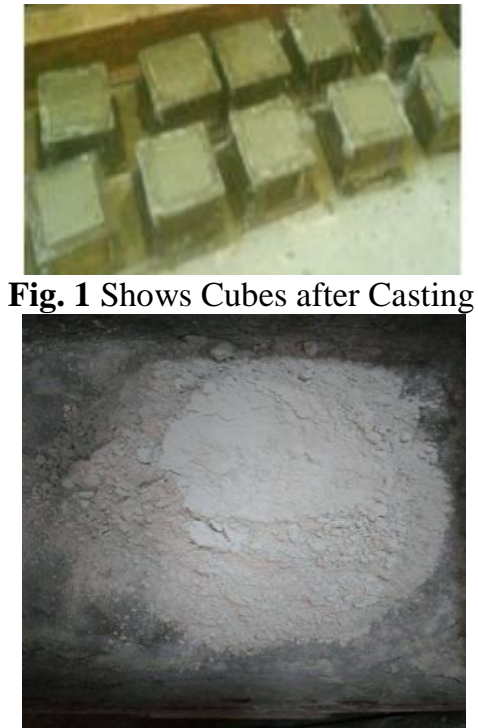

Fig. 2 Shows GGBS

\section{TEST RESULTS}

\subsection{Weight Loss and Residual Compressive Strength}

The tables 13 to 15 and Figs 3 to 6 shows the weights , percentage loss of weights, compressive strengths and percentage loss of compressive strengths of controlled and geopolymer concrete specimens exposed to $5 \%$ concentration of $\mathrm{HCL}$ and $\mathrm{H}_{2} \mathrm{SO}_{4}$ solutions for various curing methods. From the tables and graphs it is observed that as the immersion period increases the percentage loss of compressive strength and weights are increased for both the grades and in both the acid solutions such as HCL and $\mathrm{H}_{2} \mathrm{SO}_{4}$.

Table 13: Weight Loss in Percentage of Controlled (M30 \& M50) \& Geopolymer Concrete (G30 \& G50) when immersed in 5\% concentrations of various Acids and Curing methods

\begin{tabular}{|c|c|c|c|c|c|c|c|c|}
\hline \multirow[t]{2}{*}{ Sl.No. } & \multirow{2}{*}{\multicolumn{2}{|c|}{ Type of Concrete }} & \multirow{2}{*}{$\begin{array}{l}\text { Weights } \quad(\mathrm{kg}) \\
\text { before } \\
\text { Immersion }\end{array}$} & \multirow{2}{*}{$\begin{array}{l}\text { Immersion } \\
\text { Period } \\
\text { In Days }\end{array}$} & \multicolumn{2}{|c|}{$\begin{array}{l}\text { Weights }(\mathrm{kg}) \text { after } \\
\text { Immersion in Acids }\end{array}$} & \multicolumn{2}{|c|}{$\begin{array}{l}\text { Loss of Weights in } \\
\text { Percentage after } \\
\text { Immersion in Acids }\end{array}$} \\
\hline & & & & & HCL & $\mathrm{H}_{2} \mathrm{SO}_{4}$ & $\mathrm{HCL}$ & $\mathrm{H}_{2} \mathrm{SO}_{4}$ \\
\hline \multirow{6}{*}{1} & \multicolumn{2}{|l|}{ M30 } & 2.44 & \multirow{6}{*}{15} & 2.20 & 2.35 & 9.67 & 3.76 \\
\hline & \multirow[b]{2}{*}{ G30 } & Oven Cured & 2.23 & & 2.18 & 2.19 & 2.45 & 1.86 \\
\hline & & $\begin{array}{l}\text { Ambient } \\
\text { Cured }\end{array}$ & 2.24 & & 2.19 & 2.20 & 2.44 & 1.84 \\
\hline & \multicolumn{2}{|l|}{ M50 } & 2.50 & & 2.17 & 2.47 & 13.18 & 1.38 \\
\hline & \multirow[b]{2}{*}{ G50 } & Oven Cured & 2.30 & & 2.16 & 2.29 & 5.89 & 0.56 \\
\hline & & $\begin{array}{l}\text { Ambient } \\
\text { Cured }\end{array}$ & 2.31 & & 2.17 & 2.29 & 5.87 & 0.55 \\
\hline \multirow{6}{*}{2} & \multicolumn{2}{|l|}{ M30 } & 2.44 & \multirow{6}{*}{45} & 2.05 & 2.30 & 15.78 & 5.54 \\
\hline & \multirow[b]{2}{*}{ G30 } & Oven Cured & 2.23 & & 2.06 & 2.16 & 7.65 & 3.33 \\
\hline & & $\begin{array}{l}\text { Ambient } \\
\text { Cured }\end{array}$ & 2.24 & & 2.07 & 2.17 & 7.62 & 3.32 \\
\hline & \multicolumn{2}{|l|}{ M50 } & 2.50 & & 2.04 & 2.44 & 18.51 & 2.37 \\
\hline & \multirow[b]{2}{*}{ G50 } & Oven Cured & 2.30 & & 2.06 & 2.26 & 10.24 & 1.67 \\
\hline & & $\begin{array}{l}\text { Ambient } \\
\text { Cured }\end{array}$ & 2.31 & & 2.07 & 2.27 & 10.21 & 1.66 \\
\hline \multirow[b]{2}{*}{3} & \multicolumn{2}{|c|}{ M30 } & 2.44 & \multirow[b]{2}{*}{75} & 2.01 & 2.27 & 17.75 & 6.92 \\
\hline & G30 & Oven Cured & 2.23 & & 2.03 & 2.13 & 9.12 & 4.54 \\
\hline
\end{tabular}




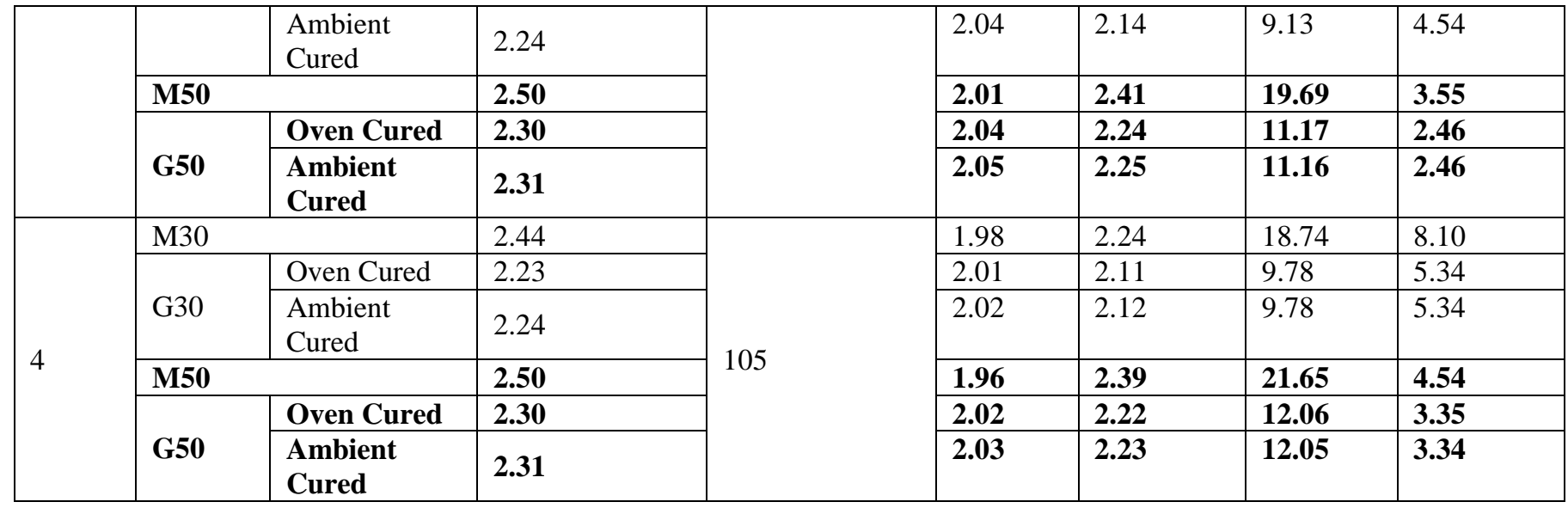

Table 14: Compressive Strength Loss in Percentage of Controlled (M30 \& M50) \& Geopolymer Concrete (G30 \& G50) when immersed in $5 \%$ concentrations of various Acids and Curing methods

\begin{tabular}{|c|c|c|c|c|c|c|c|c|}
\hline \multirow[t]{2}{*}{ Sl.No. } & \multirow{2}{*}{\multicolumn{2}{|c|}{ Concrete Type }} & \multirow{2}{*}{$\begin{array}{l}\text { Compressive } \\
\text { Strength (MPa) } \\
\text { at } 28 \text { days } \\
\text { before } \\
\text { Immersion }\end{array}$} & \multirow{2}{*}{$\begin{array}{l}\text { Immersion } \\
\text { Period } \\
\text { In Days }\end{array}$} & \multicolumn{2}{|c|}{$\begin{array}{l}\text { Compressive Strength } \\
(\mathrm{MPa}) \quad \text { after } \\
\text { Immersion in Acids }\end{array}$} & \multicolumn{2}{|c|}{$\begin{array}{l}\text { Loss of Compressive } \\
\text { Strength in Percentage } \\
\text { after Immersion in Acids }\end{array}$} \\
\hline & & & & & HCL & $\mathrm{H}_{2} \mathrm{SO}_{4}$ & HCL & $\mathrm{H}_{2} \mathrm{SO}_{4}$ \\
\hline \multirow{6}{*}{1} & \multicolumn{2}{|l|}{ M30 } & 38.62 & \multirow{6}{*}{15} & 37.11 & 36.36 & 3.90 & 5.86 \\
\hline & \multirow{2}{*}{ G30 } & Oven Cured & 38.45 & & 37.48 & 36.97 & 2.52 & 3.84 \\
\hline & & Ambient Cured & 37.10 & & 36.20 & 35.72 & 2.42 & 3.72 \\
\hline & \multicolumn{2}{|l|}{ M50 } & 58.42 & & 56.31 & 54.62 & 3.61 & 6.50 \\
\hline & & Oven Cured & 59.75 & & 58.37 & 56.79 & 2.31 & 4.95 \\
\hline & G50 & Ambient Cured & 58.36 & & 57.09 & 55.69 & 2.17 & 4.56 \\
\hline \multirow{6}{*}{2} & \multicolumn{2}{|l|}{ M30 } & 38.62 & \multirow{6}{*}{45} & 36.41 & 35.43 & 5.71 & 8.27 \\
\hline & \multirow{2}{*}{ G30 } & Oven Cured & 38.45 & & 36.89 & 36.03 & 4.05 & 6.29 \\
\hline & & Ambient Cured & 37.10 & & 35.62 & 34.82 & 4.00 & 6.15 \\
\hline & \multicolumn{2}{|l|}{ M50 } & 58.42 & & 55.41 & 54.09 & 5.15 & 7.41 \\
\hline & \multirow{2}{*}{ G50 } & Oven Cured & 59.75 & & 57.10 & 55.76 & 4.43 & 6.67 \\
\hline & & Ambient Cured & 58.36 & & 55.84 & 54.53 & 4.31 & 6.56 \\
\hline \multirow{6}{*}{3} & \multicolumn{2}{|l|}{ M30 } & 38.62 & & 35.71 & 33.04 & 7.52 & 14.44 \\
\hline & \multirow{2}{*}{ G30 } & Oven Cured & 38.45 & & 36.57 & 34.15 & 4.90 & 11.18 \\
\hline & & Ambient Cured & 37.10 & & 35.34 & 33.02 & 4.74 & 10.99 \\
\hline & \multicolumn{2}{|l|}{ M50 } & 58.42 & 75 & 54.19 & 51.46 & 7.23 & 11.92 \\
\hline & \multirow{2}{*}{ G50 } & Oven Cured & 59.75 & & 56.26 & 53.16 & 5.84 & 11.03 \\
\hline & & Ambient Cured & 58.36 & & 55.03 & 51.99 & 5.71 & 10.90 \\
\hline \multirow{6}{*}{4} & \multicolumn{2}{|l|}{ M30 } & 38.62 & \multirow{6}{*}{105} & 35.17 & 31.59 & 8.93 & 18.20 \\
\hline & \multirow{2}{*}{ G30 } & Oven Cured & 38.45 & & 35.65 & 32.66 & 7.27 & 15.06 \\
\hline & & Ambient Cured & 37.10 & & 34.48 & 31.56 & 7.05 & 14.92 \\
\hline & \multicolumn{2}{|l|}{ M50 } & 58.42 & & 53.32 & 50.43 & 8.73 & 13.67 \\
\hline & \multirow{2}{*}{ G50 } & Oven Cured & 59.75 & & 54.83 & 52.16 & 8.23 & 12.71 \\
\hline & & Ambient Cured & 58.36 & & 53.64 & 51.03 & 8.08 & 12.56 \\
\hline
\end{tabular}




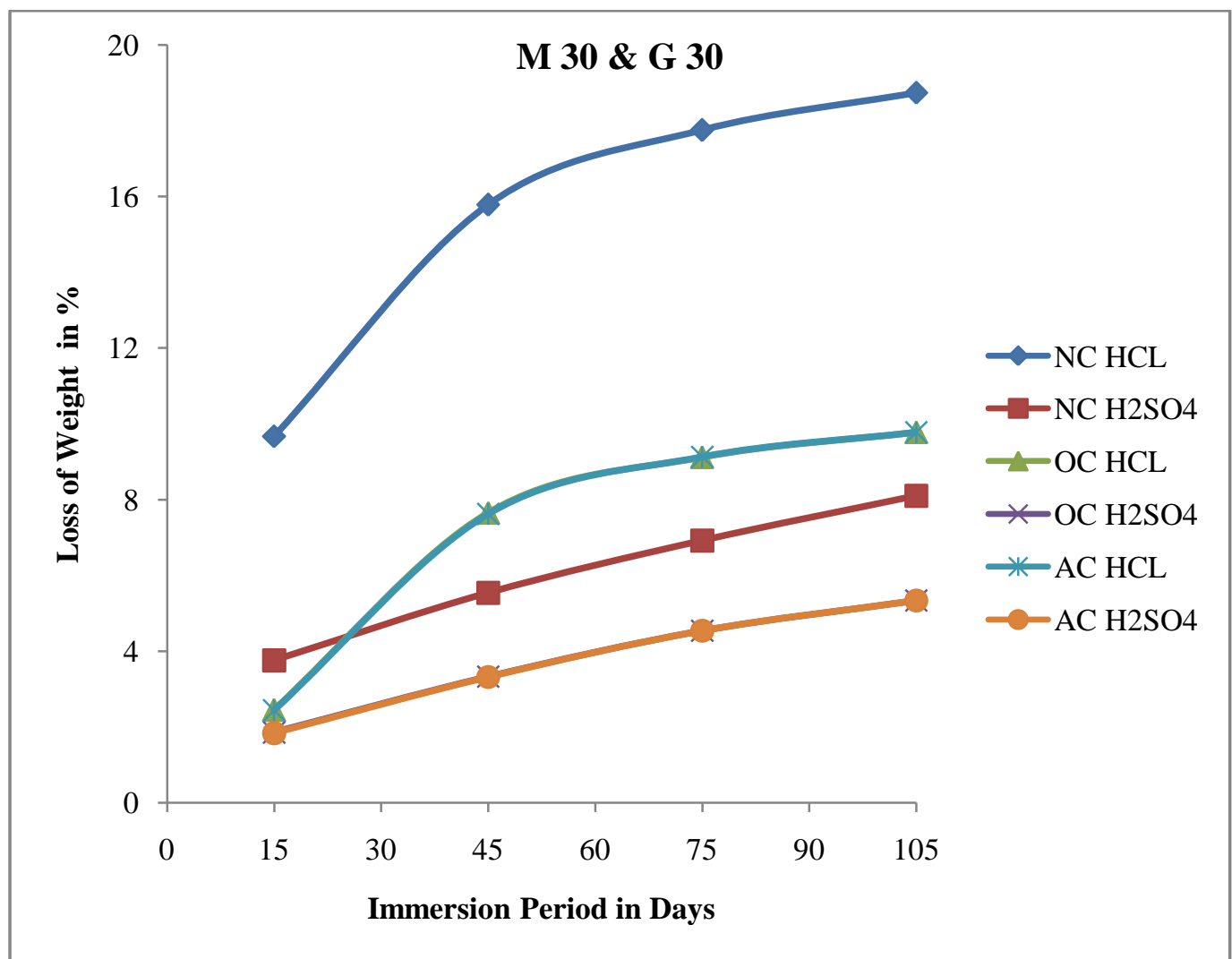

Fig 3: Weight Loss in Percentage of Controlled (M30) \& Geopolymer Concrete (G30) when immersed in 5\% concentrations of various Acids and various Curing methods

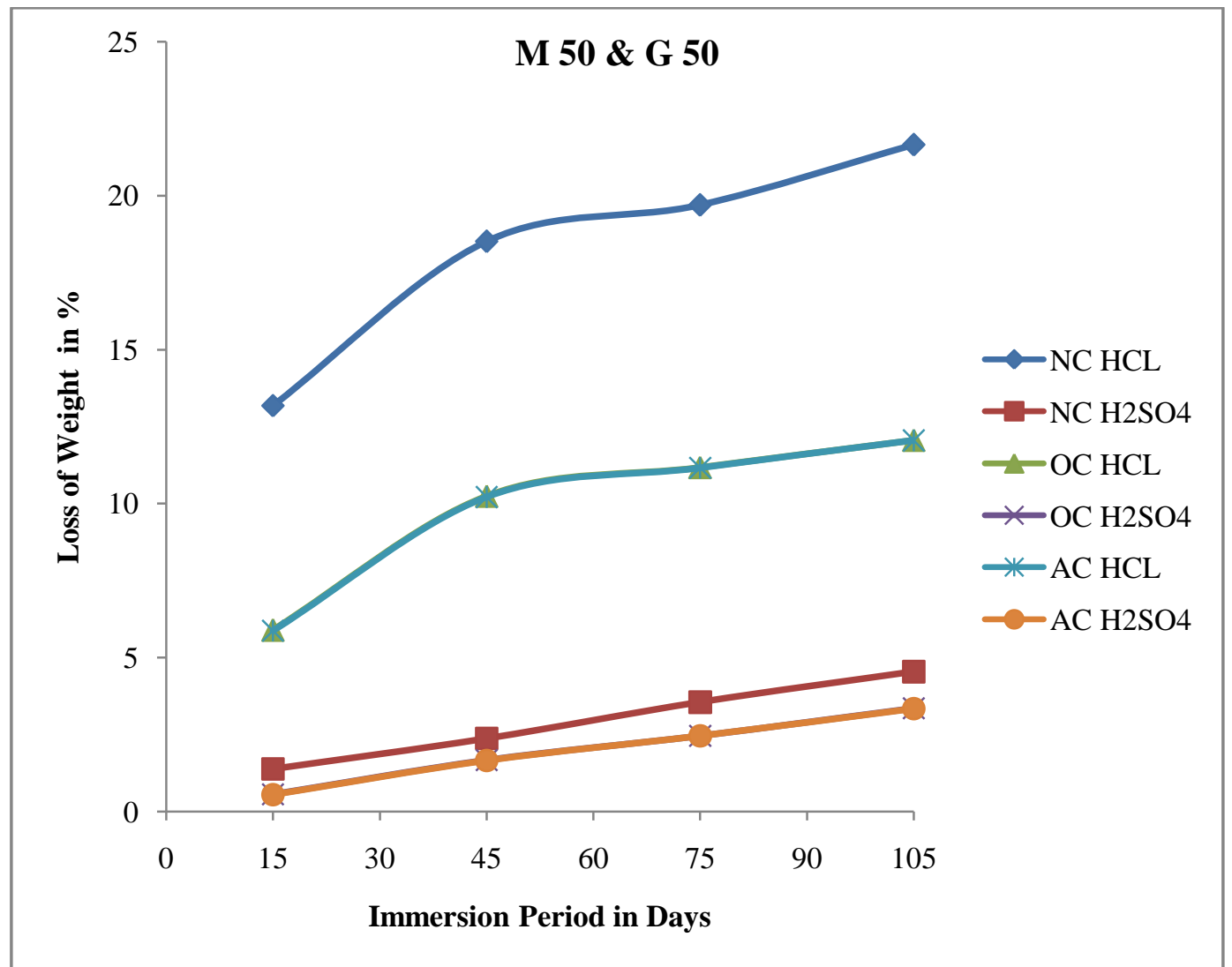

Fig 4: Weight Loss in Percentage of Controlled (M50) \& Geopolymer Concrete (G50) when immersed in 5\% concentrations of various Acids and various Curing methods 


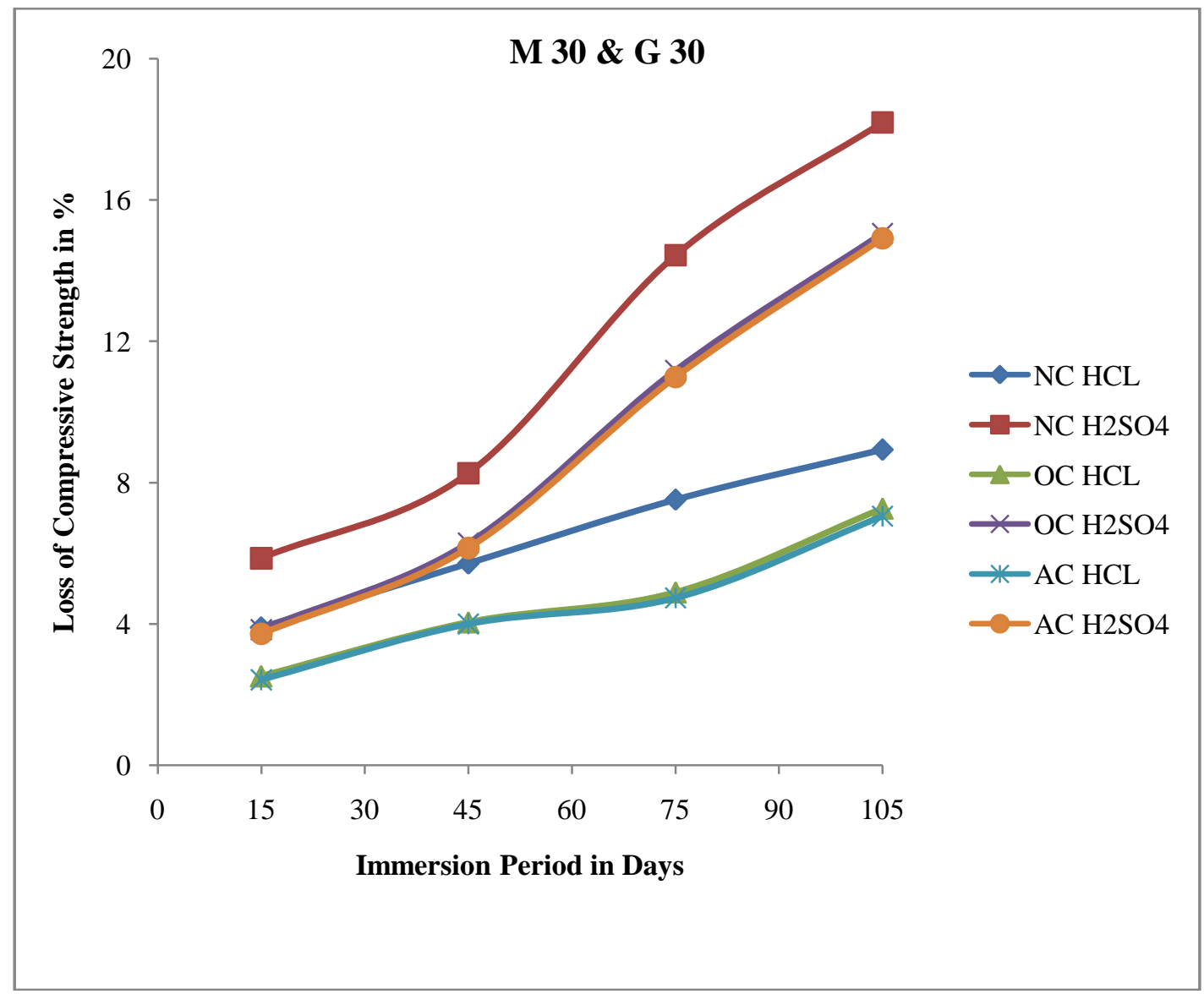

Fig 5: Loss of Compressive Strength in Percentage of Controlled (M30) \& Geopolymer Concrete (G30) when immersed in 5\% concentrations of various Acids and various Curing methods

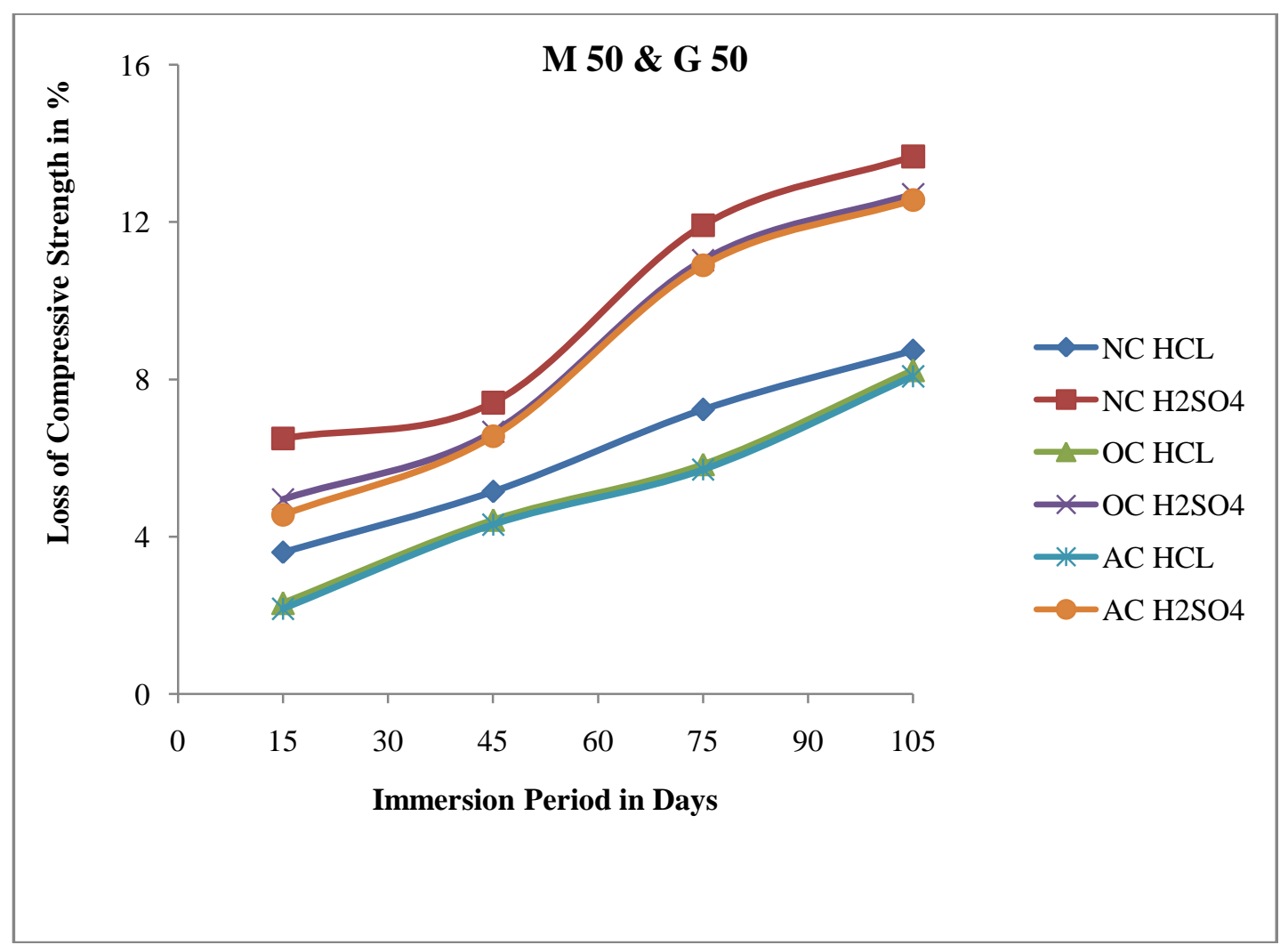

Fig 6: Loss of Compressive Strength in Percentage of Controlled (M50) \& Geopolymer Concrete (G50) when immersed in 5\% concentrations of various Acids and various Curing methods 


\subsection{Acid Durability Factors (ADFs) and Acid Attack}

\section{Factors (AAFs)}

\subsubsection{Acid Durability Factors}

The ADFs is to be calculated as below.

$\mathrm{ADF}=\mathrm{Sr}(\mathrm{N} / \mathrm{M})$

where, $\mathrm{Sr}=$ relative strength at $\mathrm{N}$ days, $(\%)$

$\mathrm{N}=$ no. of days at which the durability factor is required.

$\mathrm{M}=$ no. of days at which the exposure is to be terminated.

Acid attack test was terminated at 105 days. So, $\mathrm{M}$ is taken as 105 in this case.

\subsubsection{Acid Attack Factors}

The extent of deterioration at each corner of the struck face and the opposite face is measured in terms of the solid diagonals (in $\mathrm{mm}$ ) for each of the two cubes and the "Acid Attack Factors" (AAFs) per face is calculated as follows.

$\mathrm{AAF}=($ Loss in mm on eight corners of each of 2 cubes $) / 4$ The table 15 and Figs 7 to 10 shows the Acid Durability Factors (ADFs) and Acid Attack Factors (AAFs) of controlled and geopolymer concrete specimens exposed to $5 \%$ concentration of $\mathrm{HCL}$ and $\mathrm{H}_{2} \mathrm{SO}_{4}$ solutions for various curing methods. From the tables and graphs it is observed that the Acid Durability Factors (ADFs) increased, whereas the Acid Attack Factors (AAFs) decreased for geopolymer concrete when it is compared with controlled concrete for both the grades and in both the acid solutions such as HCL and $\mathrm{H}_{2} \mathrm{SO}_{4}$.

Table 15: Acid Durability Factors (ADFs) and Acid Attack Factors (AAFs) of Controlled (M30 \& M50) \& Geopolymer Concrete (G30 \& G50) specimens when immersed in 5\% concentrations of various Acids and Curing methods

\begin{tabular}{|c|c|c|c|c|c|c|c|}
\hline \multirow[t]{2}{*}{ Sl.No. } & \multirow{2}{*}{\multicolumn{2}{|c|}{ Type of Concrete }} & \multirow{2}{*}{$\begin{array}{l}\text { Immersion } \\
\text { Period } \\
\text { In Days }\end{array}$} & \multicolumn{2}{|c|}{$\begin{array}{l}\text { Acid Durability Factors } \\
\text { (ADFs) }\end{array}$} & \multicolumn{2}{|c|}{ Acid Attack Factors (AAFs) } \\
\hline & & & & HCL & $\mathrm{H}_{2} \mathrm{SO}_{4}$ & HCL & $\mathrm{H}_{2} \mathrm{SO}_{4}$ \\
\hline \multirow{6}{*}{1} & \multicolumn{2}{|l|}{ M30 } & \multirow{6}{*}{15} & 13.73 & 13.45 & 0.11 & 0.13 \\
\hline & \multirow{2}{*}{ G30 } & Oven Cured & & 13.93 & 13.74 & 0.00 & 0.00 \\
\hline & & Ambient Cured & & 13.94 & 13.75 & 0.00 & 0.00 \\
\hline & \multicolumn{2}{|l|}{ M50 } & & 13.77 & 13.36 & 0.09 & 0.12 \\
\hline & \multirow{2}{*}{ G50 } & Oven Cured & & 13.96 & 13.58 & $\mathbf{0 . 0 0}$ & $\mathbf{0 . 0 0}$ \\
\hline & & Ambient Cured & & 13.97 & 13.63 & $\mathbf{0 . 0 0}$ & 0.00 \\
\hline \multirow{6}{*}{2} & \multicolumn{2}{|l|}{ M30 } & \multirow{6}{*}{45} & 40.40 & 39.32 & 0.45 & 0.52 \\
\hline & G.3O & Oven Cured & & 41.12 & 40.16 & 0.12 & 0.14 \\
\hline & Gov & Ambient Cured & & 41.15 & 40.22 & 0.12 & 0.14 \\
\hline & \multicolumn{2}{|l|}{ M50 } & & 40.65 & 39.68 & 0.36 & 0.42 \\
\hline & \multirow{2}{*}{ G50 } & Oven Cured & & 40.96 & 39.99 & $\mathbf{0 . 1 0}$ & 0.11 \\
\hline & & Ambient Cured & & 41.01 & 40.04 & 0.10 & 0.11 \\
\hline \multirow{6}{*}{3} & \multicolumn{2}{|l|}{ M30 } & \multirow{6}{*}{75} & 66.01 & 61.11 & 0.72 & 0.78 \\
\hline & G30 & Oven Cured & & 67.94 & 63.44 & 0.18 & 0.23 \\
\hline & & Ambient Cured & & 68.04 & 63.57 & 0.18 & 0.23 \\
\hline & \multicolumn{2}{|l|}{ M50 } & & 66.26 & 62.92 & 0.54 & 0.61 \\
\hline & \multirow{2}{*}{ G50 } & Oven Cured & & 67.26 & 63.55 & 0.26 & 0.29 \\
\hline & & Ambient Cured & & 67.35 & 63.63 & 0.26 & 0.29 \\
\hline \multirow{6}{*}{4} & M30 & & \multirow{6}{*}{105} & 91.07 & 81.79 & 0.82 & 0.87 \\
\hline & & Oven Cured & & 92.72 & 84.94 & 0.24 & 0.28 \\
\hline & 80 & Ambient Cured & & 92.94 & 85.07 & 0.24 & 0.28 \\
\hline & \multicolumn{2}{|l|}{ M50 } & & 91.27 & 86.32 & 0.62 & 0.67 \\
\hline & \multirow{2}{*}{ G50 } & Oven Cured & & 91.77 & 87.29 & 0.28 & 0.31 \\
\hline & & Ambient Cured & & 91.91 & 87.44 & 0.28 & 0.31 \\
\hline
\end{tabular}




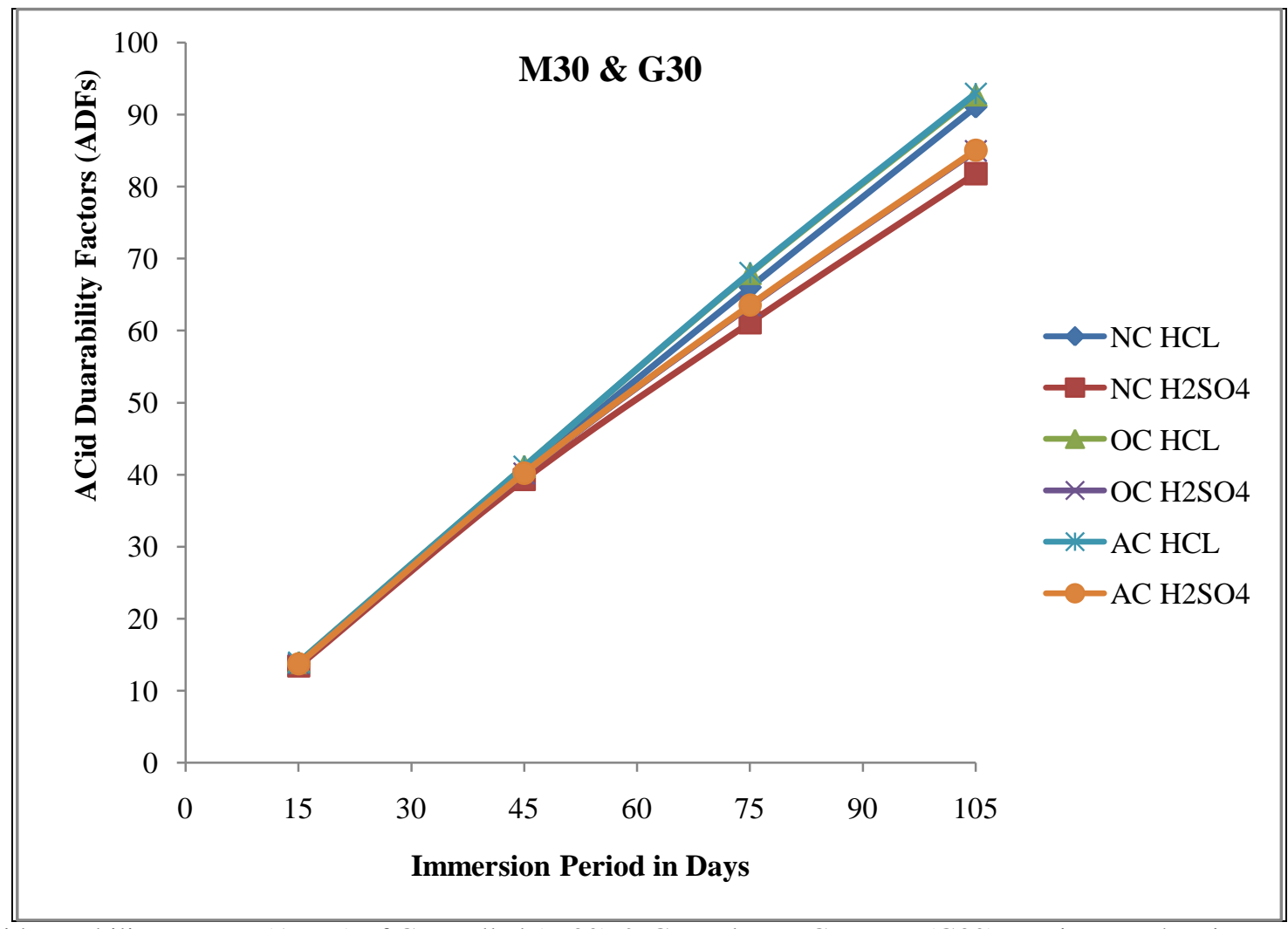

Fig 7: Acid Durability Factors (ADFs) of Controlled (M30) \& Geopolymer Concrete (G30) specimens when immersed in 5\% concentrations of various Acids and various Curing methods

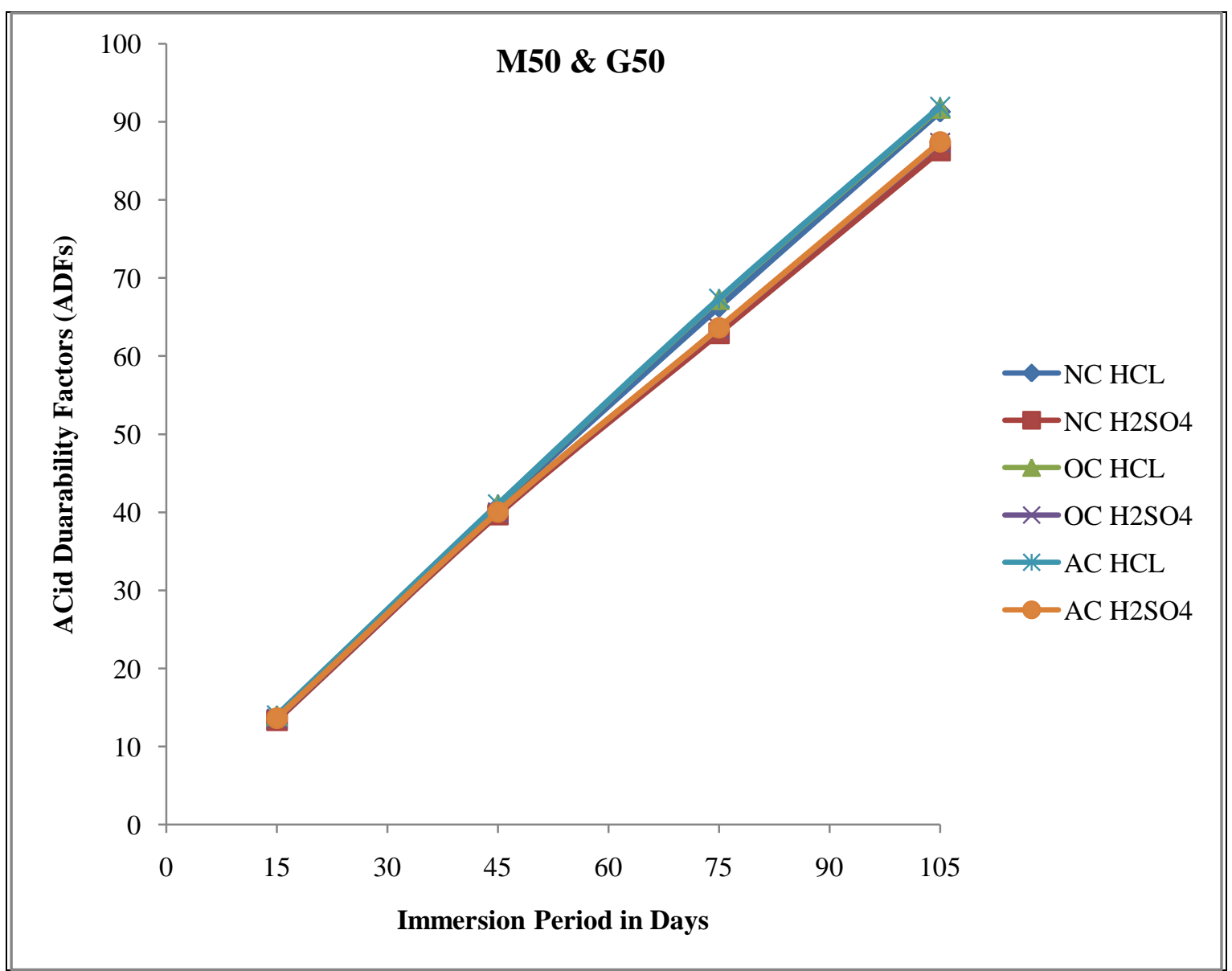

Fig 8: Acid Durability Factors (ADFs) of Controlled (M50) \& Geopolymer Concrete (G50) specimens when immersed in 5\% concentrations of various Acids and various Curing methods 


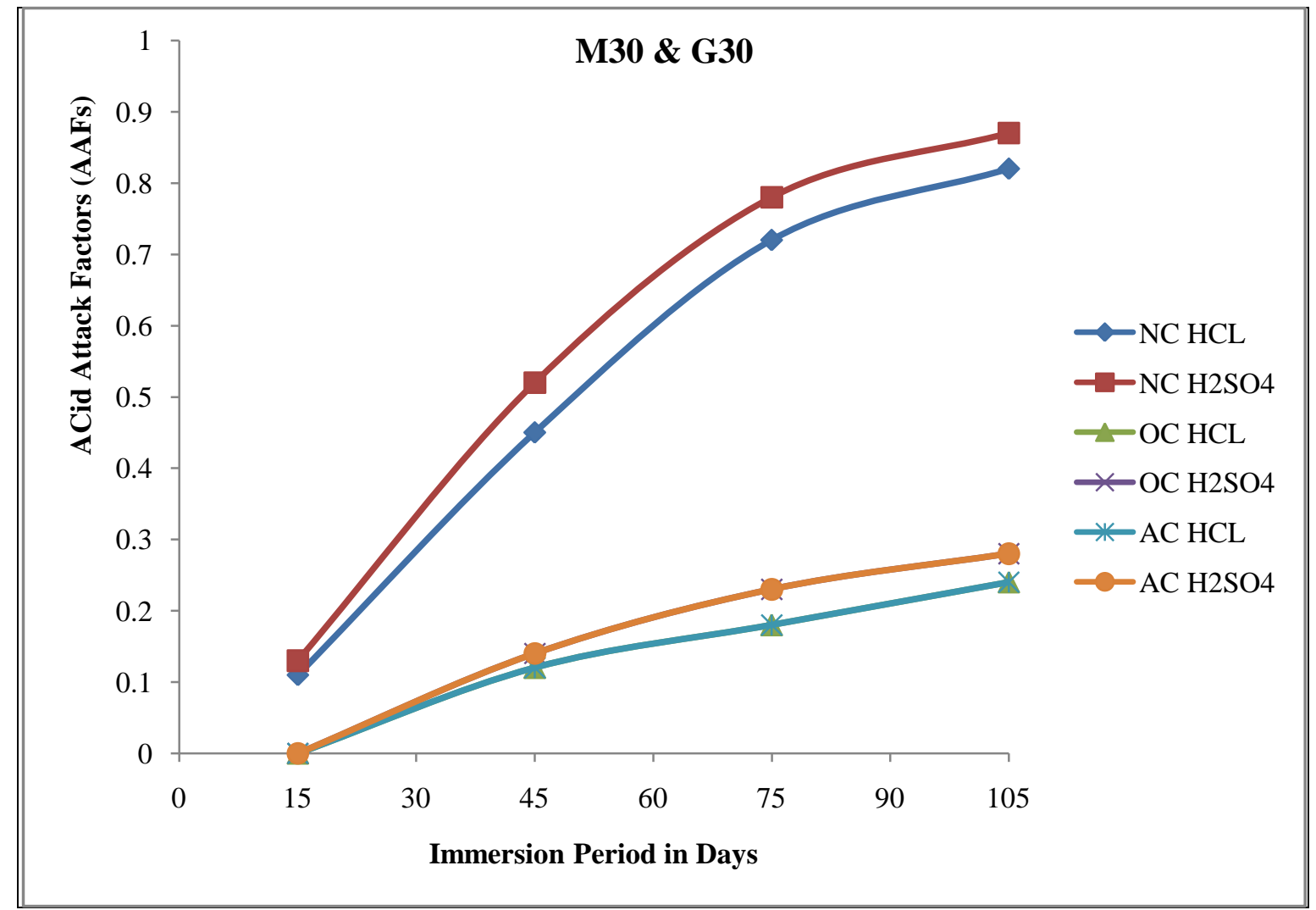

Fig 9: Acid Attack Factors (AAFs) of Controlled (M30) \& Geopolymer Concrete (G30) specimens when immersed in 5\% concentrations of various Acids and various Curing methods

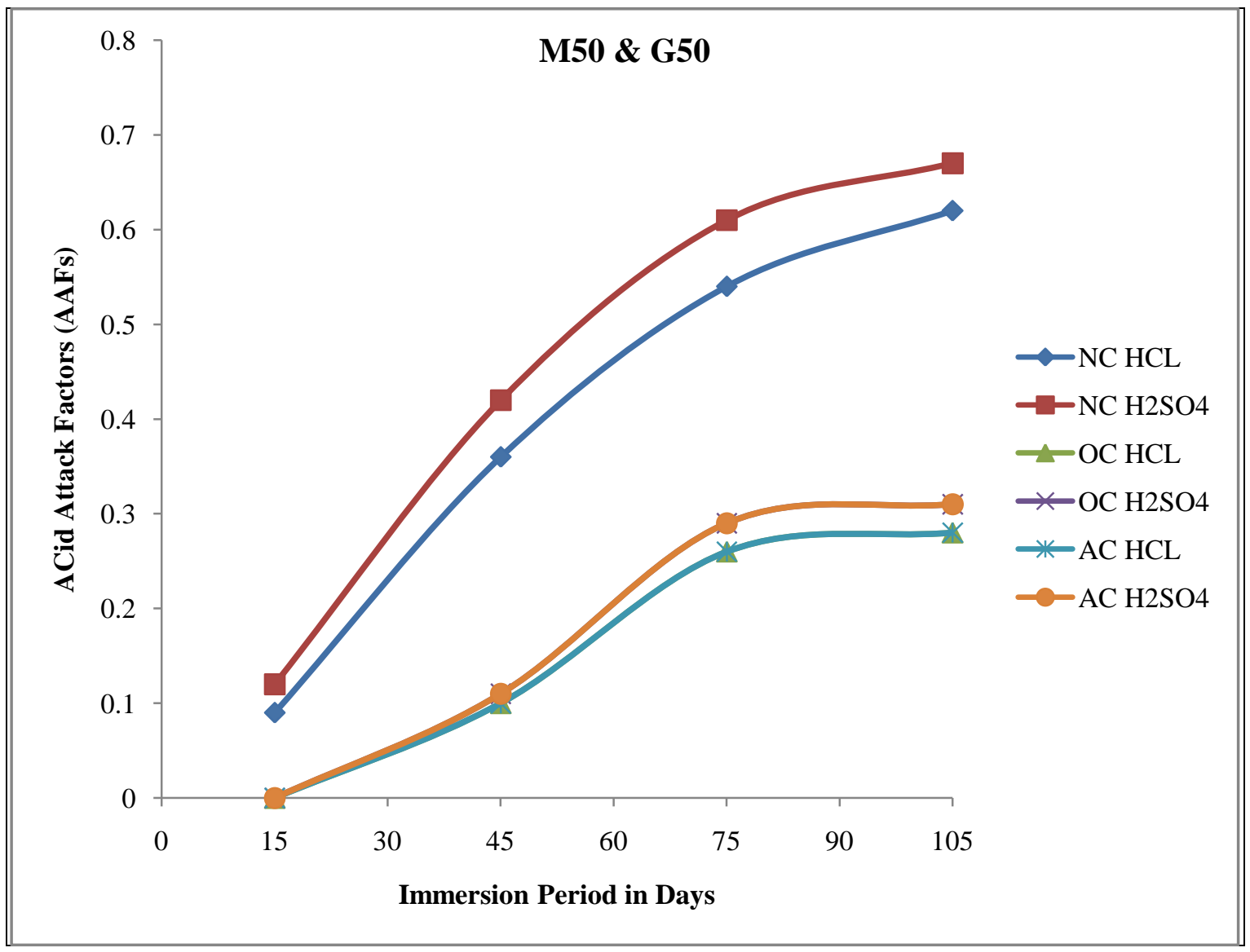

Fig 10: Acid Attack Factors (AAFs) of Controlled (M50) \& Geopolymer Concrete (G50) specimens when immersed in 5\% concentrations of various Acids and various Curing methods 


\section{CONCLUSIONS:}

The following specific conclusions can be drawn from the present experimental investigation

[1]. When the specimens are exposed to hydrochloric and sulphuric acids, the percentage loss of compressive strength and weights are increased as the immersion period increases for both the grades of controlled and geopolymer concrete.

[2]. The compressive strength loss of controlled concrete specimens when exposed to hydrochloric acid is in the range of 3.61 to $8.93 \%$, where as it is about 2.52 to $8.23 \%$ in case of geopolymer concrete. Thus, geopolymer concrete is more resistant than controlled concrete.

[3]. The compressive strength loss of controlled concrete specimens when exposed to sulphuric acid is in the range of 5.86 to $18.20 \%$, where as it is about 3.72 to $15.06 \%$ in case of geopolymer concrete. Thus, geopolymer concrete is more resistant than controlled concrete.

[4]. The loss of weight of controlled concrete specimens when exposed to hydrochloric and sulphuric acids is more than that of geopolymer concrete. Therefore it can be said that geopolymer concrete has more dimension stability than controlled concrete.

[5]. It can be inferred that geopolymer concrete is more durable in terms of 'Acid Durability Factors' and is less attacked in terms of 'Acid Attack Factors' than controlled concrete at all the ages for both the grades and can perform better in severe aggressive environments due to its high impermeability and alkalinity of concrete mass.

[6]. It can be concluded that the sulphuric acid environment is more severe than the hydrochloric acid since the strength loss is more in sulphuric acid.

[7]. It can be concluded that the loss of compressive strengths and weights are decreased as the grade of concrete is increased in both controlled and geopolymer concrete.

\section{REFERENCES}

[1]. J. Davidovits, Geopolymers: inorganic polymeric new materials, J. Therm. Anal. 37 (1991) 1633-1656, http://dx.doi.org/10.1007/BF01912193.

[2]. E.I. Diaz, E.N. Allouche, S. Eklund, Factors affecting the suitability of fly ash as source material for geopolymers, Fuel 89 (2010) 992-996, http://dx.doi.org/10.1016/j.fuel.2009.09.012.

[3]. Z. Zhang, X. Yao, H. Zhu, Potential application of geopolymers as protection coatings for marine concrete I. Basic properties, Appl. Clay Sci. 49 (1) (2010) 1-6..

[4]. Allahverdi A, Skvara F. Sulfuric acid attack on hardened paste of geopolymer cements - Part 1 . Mechanism of corrosion at relatively high concentrations. Ceram-Silik 2005;49:225-9.

[5]. Kolli Ramujee and Dr.M.Potharaju, "Development of Mix Design for Low Calcium based Geopolymer concrete in Ordinary, Standard and High Strength Grades”, ICI Journal, July-September, 2013, pp 29-34.
[6]. Rangan, B.V., (2008), Mix design and production of fly ash based geopolymer concrete, Indian Concrete Journal, 82(5), 7 - 15.

[7]. Rajamane, N. P, Nataraja M. C, Dattatreya, J. K, Lakshamanan, N and Sabitha, D, (2012), Sulphate resistance and eco-friendliness of geopolymer concrete, The Indian Concrete Journal, Jan., pp 13-22.

[8]. Hardjito, D., Wallah, S.E., Sumajouw, D.M.J., and Rangan, B.V., (2004), On the development of fly ash based Geopolymer concrete, ACI Materials Journal, 101(52), pp 467-472.

[9]. T. Bakharev, Resistance of geopolymer materials to acid attack, Cem. Concr. Res. 35 (2005) 658-670, http://dx.doi.org/10.1016/j.cemconres.2004. 06.005.

[10]. Mustafa Al Bakri, A.M., Kamarudin, H., Bnhussain, M., Khairul Nizar, Rafiza, A. R., and Zarina, Y., (2011), Microstructure of different $\mathrm{NaOH}$ molarity of fly ash based green polymeric cement, Journal of Engineering and Technology Research, 32(2), pp 4449

[11]. Davidovits, J., (1994), Properties of geopolymer cements, Proceedings of first International conference on alkaline cements and concretes, 1, SRIBM, Kiev, Ukraine, pp 131-149.

[12]. P. Chindaprasirt, U. Rattanasak, S. Taebuanhuad, Resistance to acid and sulfate solutions of microwaveassisted high calcium fly ash geopolymer, Mater. Struct. 46 (3) (2013) 375-381.

[13]. Davidovits, J.,(2002), 30 years of successes and failures in geopolymer applications-Market trends and potential breakthroughs, Proceedings of the geopolymer 2002 conference Oct28-29, Melbourne, Australia, 1-15.

[14]. Suresh Thokchom, Dr. Partha Gosh and Dr. Somnath Gosh, (2009), Acid resistance of fly ash based geopolymer mortars, International Journal of Recent Trends in Engineering, 1(6), pp 36-40.

[15]. Shetty, M. S., (2002), Concrete Technology, 5th revised edition, S.Chand and Company.

[16]. IS:2386 (Part-IV)-1963, Methods of test for aggregates for concrete-mechanical properties, Bureau of Indian standards, New Delhi.

[17]. IS:456-2000, Code of practice for plain and reinforced concrete, Bureau of Indian standards, New Delhi.

[18]. IS:383-1970, Specification for coarse and fine aggregates from natural sources for concrete, Bureau of Indian standards, New Delhi.

\section{BIOGRAPHIES}

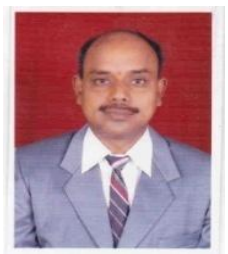

T.Srinivas is working as an associate professor in the Department of Civil Engineering, Gokaraju Rangaraju Institute of Engineering and Technology, Hyderabad, Telangana, India and pursuing his $\mathrm{PhD}$ in JNTUH, Hyderabad. His areas of research interest are mainly focused on the utilization of GGBS \& coal ash (fly ash and bottom ash), special concrete, structural analysis and design of different structures. 


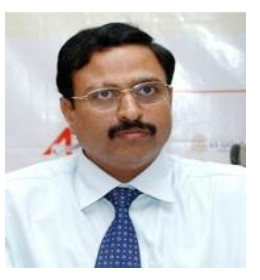

Dr. N.V. Ramana Rao is the professor of civil engineering at JNTUH College of Engineering, Hyderabad. His research interests include special concretes, structural design, finite element analysis, analysis and design of complex structures, computer application and Structural optimization. He has been associated with a number of design projects, particularly bridges \& high rise structures. He has more than 24 years of experience in teaching, research and consultancy. He has published more than 40 papers in several national and international refereed journals. 